\title{
Synthesis, Structural Characterization, and Optical Properties of Benzene-Fused Tetracyclic and Pentacyclic Stiboles
}

\author{
Mio Matsumura ${ }^{1}$, Yuki Matsuhashi ${ }^{1}$, Masato Kawakubo ${ }^{1}$, Tadashi Hyodo ${ }^{2}$, Yuki Murata ${ }^{1} \mathbb{}$, \\ Masatoshi Kawahata ${ }^{2,+}$, Kentaro Yamaguchi ${ }^{2}$ and Shuji Yasuike ${ }^{1, *(D)}$ \\ 1 School of Pharmaceutical Sciences, Aichi Gakuin University, 1-100 Kusumoto-cho, Chikusa-ku, \\ Nagoya 464-8650, Japan; m-matsu@dpc.agu.ac.jp (M.M.); yuki325first@yahoo.co.jp (Y.M.); \\ masato09224@icloud.com (M.K.); y-murata@dpc.agu.ac.jp (Y.M.) \\ 2 Pharmaceutical Sciences at Kagawa Campus, Tokushima Bunri University, 1314-1 Shido, Sanuki, \\ Kagawa 769-2193, Japan; s170331@stu.bunri-u.ac.jp (T.H.); kawahatam@ac.shoyaku.ac.jp (M.K.); \\ kyamaguchi@kph.bunri-u.ac.jp (K.Y.) \\ * Correspondence: s-yasuik@dpc.agu.ac.jp; Tel.: +81-52-757-6774 \\ + Present Address: Showa Pharmaceutical University, 3-3165 Higashi-Tamagawagakuen, Machida, \\ Tokyo 194-8543, Japan.
}

check for updates

Citation: Matsumura, M.;

Matsuhashi, Y.; Kawakubo, M.;

Hyodo, T.; Murata, Y.; Kawahata, M.; Yamaguchi, K.; Yasuike, S. Synthesis, Structural Characterization, and

Optical Properties of Benzene-Fused Tetracyclic and Pentacyclic Stiboles.

Molecules 2021, 26, 222.

https://doi.org/10.3390/

molecules 26010222

Academic Editors: Irina A. Balova and

Alexander S. Antonov

Received: 23 November 2020

Accepted: 28 December 2020

Published: 4 January 2021

Publisher's Note: MDPI stays neutral with regard to jurisdictional clai$\mathrm{ms}$ in published maps and institutional affiliations.

Copyright: (C) 2021 by the authors. Licensee MDPI, Basel, Switzerland. This article is an open access article distributed under the terms and conditions of the Creative Commons Attribution (CC BY) license (https:// creativecommons.org/licenses/by/ $4.0 /)$.

\begin{abstract}
The expectation that antimony $(\mathrm{Sb})$ compounds should display phosphorescence emissions based on the "heavy element effect" prompted our interest in the introduction of antimony to a biaryl as the bridging atom in a fused heterole system. Herein, the synthesis, molecular structures, and optical properties of novel benzene-fused heteroacenes containing antimony or arsenic atoms are described. The stiboles and arsole were prepared by the condensation of dibromo(phenyl)stibane or dichloro(phenyl)arsine with dilithium intermediates derived from the corresponding dibromo compounds. Nuclear magnetic resonance (NMR) spectroscopy and X-ray crystal analysis revealed that the linear pentacyclic stibole was highly symmetric in both the solution and crystal states. In contrast, the curved pentacyclic stibole adopted a helical structure in solution, and surprisingly, only $\mathrm{M}$ helical molecules were crystallized from the racemate. All synthesized compounds produced very weak or no emissions at room temperature or in the solid state. In contrast, the linear penta- and tetracyclic stiboles exhibited clear phosphorescence emissions in the $\mathrm{CHCl}_{3}$ frozen matrix at $77 \mathrm{~K}$ under aerobic conditions.
\end{abstract}

Keywords: antimony; stibole; molecular structure; low-temperature luminescence; phosphorescence

\section{Introduction}

The development of novel $\pi$-conjugated systems and the elucidation of their optical properties to realize desired behaviors and functionalities are of current importance in the field of organic optoelectronic materials. The introduction of a group 15 elements such as phosphorus to a biaryl, as a bridge to form a fused heterole system, is of particular interest because it can further enhance conjugation due to its electronic effects [1]. For example, five-membered phospholes and their derivatives have been extensively studied as basic units of functional materials with luminescent, semiconducting, and sensing properties [2-6]. Arsoles, containing the homologous element, arsenic, have been reported as luminescent substances that are less likely to be oxidized than phospholes, although toxicity is a concern [7-11]. Antimony, another homologue located in the fifth period of group 15 elements in the periodic table, is expected to impart phosphorescence similarly to bismuth and tellurium based on the "heavy element effect", in contrast to lighter elements such as phosphorus [12-16]. Furthermore, since antimony compounds such as sodium stibogluconate (Pentostam) are used as first-line drugs for leishmaniasis [17] and are less toxic than bismuth compounds [18-20]; they have also garnered attention in the field of biology [21]. However, five-membered heterocyclic compounds containing antimony, 
known as stiboles, have received little attention with respect to their synthesis and spectrochemical behavior, including luminescence. In 1985, monocyclic stibole I (Figure 1) was synthesized by Ashe III et al., but it was unstable and resinified at room temperature under inert atmosphere [22]. The addition of fused aromatic rings effectively stabilizes I, such that the isolation of bicyclic benzo[ $b]$ stibole II and tricyclic dibenzo $[b, d]$ stibole III has been reported [23-25]. The functions of benzostibole derivatives, such as the optical resolution of central asymmetry on antimony [26] and anion sensing, are being clarified [27,28]. In 2012, Ohshita et al. reported the synthesis of benzothiophene-fused pentacyclic stibole IV \{1-(4-methylphenyl)-2,2'-di(benzo[ $b]$ thieno)stibolein $\}$ in low yield; however, almost no luminescence was observed at room temperature [29]. Subsequently, they reported both the synthesis of pyridine-fused tricyclic stibole $\mathbf{V}$ (9-phenyl-stibolo [2,3$\left.c: 5,4-c^{\prime}\right]$ dipyridine) and its phosphorescence at low temperature. They also revealed that the copper complex derived from stibole $\mathbf{V}$ and $\mathrm{Cu}_{2} \mathrm{I}_{2}\left(\mathrm{PPh}_{3}\right)_{3}$ displayed phosphorescence at room temperature [30]. We reported the synthesis and structural study of optically active 7-( $p$-tolyl)dinaphtho[2,1-b:1', $\left.2^{\prime}-d\right]$ stibole (7-Tol-DNSb) and revealed the dynamic behavior of the binaphthyl skeleton based on the $C_{2}$ symmetry axis [31]. These results show that the synthesis, structural analysis, and optical properties of the parent compound, stibole, are important for the subsequent creation of functional devices. However, there are no reports of linearly extended $\pi$-conjugated tetracyclic or pentacyclic stiboles condensed with benzene rings. Here, we present the synthesis of 5-phenylbenzo[ $b]$ naphtho[2,3- $d]$ stibole (2),

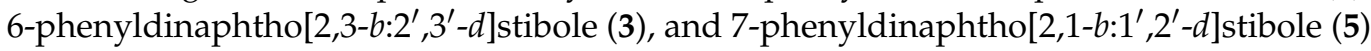
(Scheme 1) and explore the influence of the fused benzene rings on the optical properties including the phosphorescence of polycyclic benzostiboles.<smiles>C1=C[Sb](c2ccccc2)C=C1</smiles><smiles>C1=C[Sb](c2ccccc2)c2ccccc21</smiles>

II<smiles>c1ccc2c(c1)Cc1ccccc1-2</smiles><smiles>C[SbH2]</smiles>

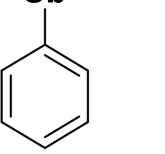

III<smiles>Cc1ccc([Se]C2=c3c(sc4ccccc34)=C2c2ccc(C)cc2)cc1</smiles>

IV<smiles>c1ccc([Se]c2cnccc2-c2ccncc2)cc1</smiles>

V

Figure 1. Related stiboles.<smiles>c1ccc([B-]2c3ccccc3-c3cc4ccccc4cc32)cc1</smiles>

$2(46 \%)$<smiles>Brc1ccc2ccccc2c1-c1c(Br)ccc2ccccc12</smiles>

$1 \mathrm{c}$
1) $t \mathrm{BuLi}$

2) $\mathrm{PhSbBr}_{2}$

1) $n \mathrm{BuLi}$ 2) $\mathrm{PhSbBr}_{2}$<smiles>Brc1cc2ccccc2cc1-c1cc2ccccc2cc1Br</smiles>
1<smiles>c1ccc([B-](c2ccccc2)c2ccc3ccccc3c2-c2ccccc2)cc1</smiles>

$5(26 \%)$
1) $n \mathrm{BuLi}$ 2) $\mathrm{PhMX}_{2}$<smiles></smiles>

3: $M=S b(54 \%)$

4: $M=$ As $(55 \%)$

Scheme 1. Synthetic stiboles and arsole. 


\section{Results and Discussion}

\subsection{Synthesis}

The structures and synthetic routes for the novel heteroacenes prepared in this study are shown in Scheme 1. The cyclization precursors, 2-bromo-3-(2-bromophenyl)naphthalene (1a) and 2,2'-dibromo-3,3'-binaphthyl (1b), were synthesized using a modification of a previously reported procedure [32] that involved the SuzukiMiyaura cross-coupling of 3-bromo-2-naphthylboronic acid with 2-bromoiodobenzene or 3-bromo-2-iodonaphthalene, respectively. Sequential treatment of dibromo compound 1a with $n$-butyllithium in dry tetrahydrofuran at $-78{ }^{\circ} \mathrm{C}$ followed by dibromo(phenyl)stibane resulted in ring closure, giving the desired product 2 in $46 \%$ yield. Compound 3 was obtained in $54 \%$ yield from 3,3'-dibromo-2,2'-binaphthyl (1) $)$ using a similar procedure. This system also afforded the analogous group 15 arsenic compound 4 in 55\% yield, using dichloro(phenyl)arsine as the electrophilic reagent. We previously reported the synthesis and molecular structure of a stibohelicene, 7-Tol-DNSb, in which the positions of the fused benzene rings were different from those in 2 [31]. However, the optical properties of that compound had no mentions at all. To further probe those properties, 7-phenyldinaphtho[2,1-b:1' $\left.2^{\prime}-d\right]$ stibole (5) was prepared from 2,2'-dibromo-1,1'-binaphthyl (1c).

\subsection{Structure Analysis}

The molecular structures of compounds $2-\mathbf{5}$ were confirmed spectroscopically $\left({ }^{1} \mathrm{H}\right.$ and ${ }^{13} \mathrm{C}-\mathrm{NMR}$, and MS). In the ${ }^{1} \mathrm{H}$ - and ${ }^{13} \mathrm{C}-\mathrm{NMR}$ spectra of linear pentacyclic stibole 3 , all the corresponding aromatic protons and carbons on the two naphthalene rings were equivalent. These results show that stibole 3 has a symmetric structure in $\mathrm{CDCl}_{3}$ solution. Pentacyclic arsole 4 also revealed a symmetrical structure in solution. In contrast, in the ${ }^{13} \mathrm{C}$-NMR spectrum of stibole 5 , which is an isomer of 3 , all the carbon signals in the two naphthalene rings were chemically nonequivalent. This result suggests that $\mathbf{5}$ adopts a curved helical structure similar to the known $S b$-tolyl derivative [31].

All the obtained heteroacenes $\mathbf{2}-\mathbf{5}$ were colorless crystalline solids. Single crystals of stiboles $\mathbf{3}$ and $\mathbf{5}$ suitable for $\mathrm{X}$-ray analysis were obtained by repeated recrystallization from benzene/hexane or $\mathrm{Et}_{2} \mathrm{O} /$ hexane as the solvent. Unfortunately, single crystals of 2 and $\mathbf{4}$ could not be obtained. The molecular structures of pentacyclic stiboles $\mathbf{3}$ and $\mathbf{5}$ obtained from single-crystal X-ray diffraction (SCXRD) analysis are illustrated in Figure 2, and selected bond lengths and angles are summarized in Table 1 . The structure obtained for linear stibole 3 reveals naphthalene wings that are slightly bent. The angle between each naphthalene ring, defined by ten carbon atoms, is $8.05^{\circ}$, and the dihedral angle of $\mathrm{C}(4)-C(5)-C(6)-C(7)$ is $0.0(13)^{\circ}$. The $\mathrm{C}-\mathrm{Sb}$ bond lengths are 2.155-2.182 $\AA$, the $\mathrm{C}(\mathrm{Ph})-\mathrm{Sb}-\mathrm{C}$ bond angles are $92.7(3)$ and $94.6(3)^{\circ}$, and the interior $\mathrm{C}-\mathrm{Sb}-\mathrm{C}$ angle in the stibole ring is $81.0(3)^{\circ}$. The sum of the bond angles around the antimony atom is $268.3^{\circ}$. The antimony center is highly pyramidalized, and the Ph substituent is situated nearly perpendicular to the stibole plane. In the packing structure, $\pi-\pi$ stacking interactions are observed along the $a$ axis. The interplanar distances between adjacent dinaphthostiboles are $3.57 \AA$ (Figure 2c). In contrast, in the case of curved stibole 5 , the $C(4)-C(5)-C(6)-C(7)$ dihedral angle is $36.3(3)^{\circ}$, and a helical structure is adopted to prevent steric strain. Surprisingly, the crystallization of racemic stibole 5 produced optically active crystals consisting of only the $\mathrm{M}$ helical structure, that is, spontaneous resolution occurred during crystallization. Because the homochiral association event involves a large entropy loss, it has been estimated that only $5-10 \%$ of organic racemates exist as conglomerates [33,34]. To the best of our knowledge, this is the first example of the spontaneous resolution of a stibole derivative. In contrast, 7-Tol-DNSb formed a racemic crystal containing both enantiomers in equal proportions, specifically, it did not resolve spontaneously [31]. The bond lengths and angles around the antimony atom in $\mathbf{5}$ are approximately the same as in linear stibole $\mathbf{3}$. Furthermore, similar bond lengths and angles have been observed among previously reported stiboles, including benzostiboles [27,35], dipyridostibole [30], and 7-tolyldinaphthostibole [31]. 
(a)
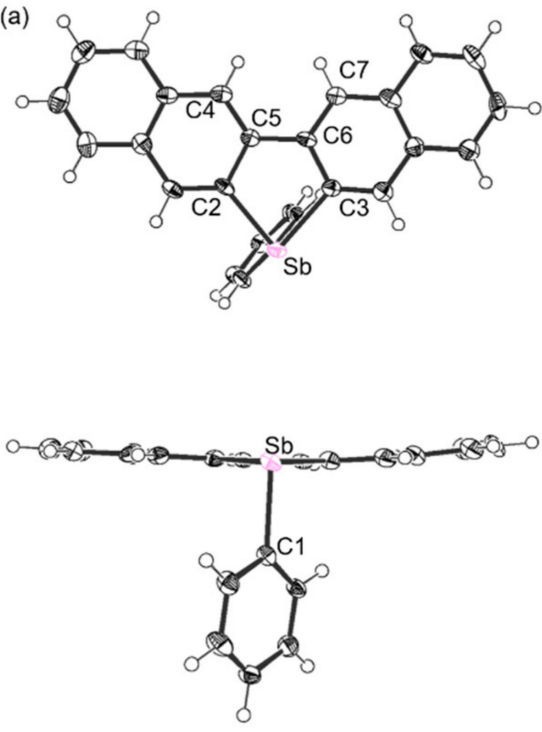

(b)

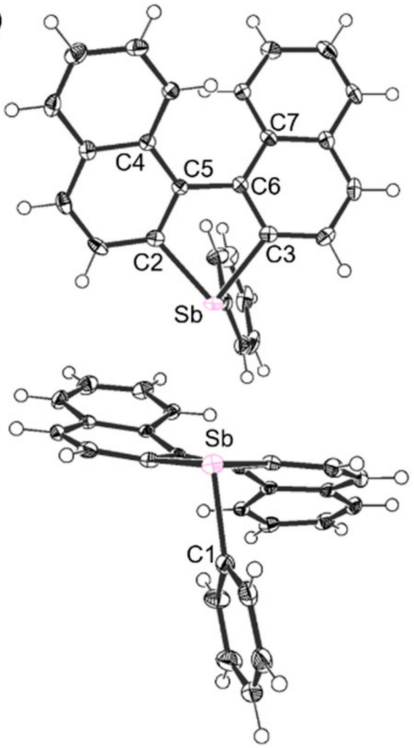

(c)
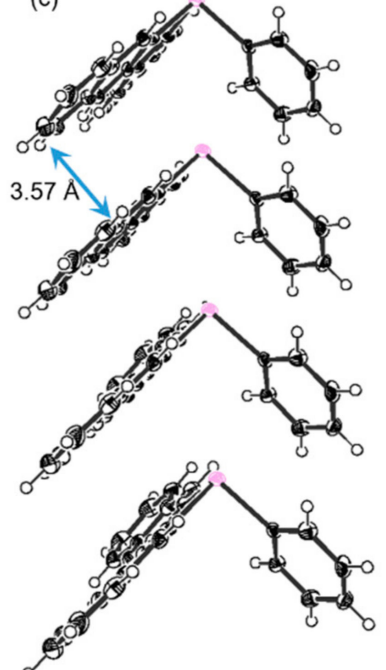

Figure 2. Crystal structures of (a) 3 and (b) 5, and (c) stacking structure of 3.

Table 1. Selected bond lengths and angles.

\begin{tabular}{cccc}
\hline & & Compound 3 & Compound 5 \\
\hline Bond length $(\AA)$ & $\mathrm{C}(1)-\mathrm{Sb}(1)$ & $2.182(9)$ & $2.158(2)$ \\
& $\mathrm{C}(2)-\mathrm{Sb}(1)$ & $2.155(10)$ & $2.138(2)$ \\
& $\mathrm{C}(3)-\mathrm{Sb}(1)$ & $2.171(8)$ & $2.146(2)$ \\
\multirow{2}{*}{ Bond angle $\left(^{\circ}\right)$} & $\mathrm{C}(2)-\mathrm{Sb}(1)-\mathrm{C}(3)$ & $81.0(3)$ & $80.03(8)$ \\
& $\mathrm{C}(1)-\mathrm{Sb}(1)-\mathrm{C}(2)$ & $92.7(3)$ & $100.33(8)$ \\
& $\mathrm{C}(1)-\mathrm{Sb}(1)-\mathrm{C}(3)$ & $94.6(3)$ & $89.47(8)$ \\
Torsion angle $\left(^{\circ}\right)$ & $\mathrm{C}(4)-\mathrm{C}(5)-\mathrm{C}(6)-\mathrm{C}(7)$ & $0.0(13)$ & $36.3(3)$ \\
\hline
\end{tabular}

\subsection{Optical Properties}

The photophysical properties of the synthesized stiboles and related compounds were evaluated, and the corresponding data are shown in Table 2 and Figure 3. The absorption maxima $\left(\lambda_{\max }\right)$ of stiboles 2 and 3 are observed at 323 and $360 \mathrm{~nm}$, respectively. Since the $\lambda_{\text {max }}$ of bicyclic benzostibole II is $313 \mathrm{~nm}$, the absorption band is red-shifted as the number of fused benzenes increases, reflecting the extended $\pi$-conjugation. Conversely, dinaphtho[2,1-b:1', $\left.2^{\prime}-d\right]$ stibole 5 has a broad absorption band at $363 \mathrm{~nm}$. It is known that the $\lambda_{\text {max }}$ of $[n]$ helicenes generally occurs at lower wavelengths than the corresponding linear-type poly(acene)s [36]. In contrast, the wavelengths of peak top positions of linear stibole 3 and curved stibole 5 are the same. Surprisingly, the absorption edge of 5 reaches over $400 \mathrm{~nm}$ and is observed in a longer wavelength region than 3 . Arsole $4\left(\lambda_{\max }\right.$ at $358 \mathrm{~nm}$ ) exhibits an absorption spectrum similar to that of stibole 3 , which indicates that the influence of the bridging heteroatom composing the five-membered ring is small.

The fluorescence spectra of stiboles 2, 3, and 5 and arsole 4 at room temperature show weak emissions with quantum efficiencies of $3 \%$ or less. This effect can be attributed to the presence of heavy atoms that promote an effective intersystem-crossing process. In the $\mathrm{CHCl}_{3}$ frozen matrix at $77 \mathrm{~K}$ under aerobic conditions, however, stiboles 2 and 3 display apparent fluorescence and phosphorescence emissions. Figure 4 shows the fluorescence spectra (a) and phosphorescence spectra (b), isolated by means of gated detection, with a delay of $27 \mathrm{~ms}$, for the compounds. These spectra clearly reveal emission bands that are composed of weaker fluorescence at 350-400 nm and stronger phosphorescence at 500-650 nm. The measured phosphorescence lifetimes are of the order of $40 \mathrm{~ms}$. On the other hand, arsole 4 shows both fluorescence and phosphorescence emissions under the same conditions, but the contribution from phosphorescence $(530-650 \mathrm{~nm})$ is less than that 
from fluorescence (350-420 nm). Further, its phosphorescence lifetime is much longer than those of the stiboles ( $205 \mathrm{~ms}$ ). In photographs at $77 \mathrm{~K}$ under UV irradiation, stiboles 2 and 3 clearly exhibit green and yellow phosphorescence emissions, respectively, whereas a blue fluorescence emission is displayed for arsole 4 (Figure 4c). However, a weak emission is observed for the helical-type stibole 5, even at 77 K (Figure S1, Supplementary Materials). Unfortunately, none of the compounds were emissive in the crystal state.

Table 2. Absorption and emissions spectroscopy data ${ }^{a}$.

\begin{tabular}{|c|c|c|c|c|c|}
\hline Compd. & $\begin{array}{l}\mathrm{UV} \lambda_{\mathrm{abs}}(\varepsilon) \\
(\mathrm{nm})\end{array}$ & $\begin{array}{l}\lambda_{\mathrm{fl}} \mathrm{b} \\
(\mathrm{nm})\end{array}$ & $\begin{array}{c}\Phi_{\mathrm{fl}} \mathrm{b}, \mathrm{c} \\
(\%)\end{array}$ & $\lambda_{\text {phos }} \mathrm{d}$ & $\begin{array}{c}\tau_{\text {phos }} \mathrm{d} \\
(\mathrm{ms})\end{array}$ \\
\hline 2 & $\begin{array}{l}268(29500) \\
323(11300)\end{array}$ & 356,373 & 1.0 & 517,529 & 40 \\
\hline 3 & $\begin{array}{l}288(54100), \\
340(20700), \\
360(3700)\end{array}$ & 365,385 & 0.5 & 551,588 & 45 \\
\hline 4 & $\begin{array}{l}266(84800), \\
341(15300), \\
358(6100)\end{array}$ & 362 & 3.0 & 537,583 & 205 \\
\hline 5 & 363 (12200) & 406.5 & 0.03 & n.d. ${ }^{\mathrm{e}}$ & n.d. ${ }^{\mathrm{e}}$ \\
\hline
\end{tabular}

a Measured in $\mathrm{CHCl}_{3} \cdot{ }^{\mathrm{b}}$ Excited at 320 for 2, 340 for $\mathbf{3}$ and 4, and $360 \mathrm{~nm}$ for $\mathbf{5} .{ }^{\mathrm{c}}$ Measured using anthracene as a standard. ${ }^{\mathrm{d}}$ Measured at $77 \mathrm{~K}$ in gated detection (delay $27 \mathrm{~ms}$ ). ${ }^{\mathrm{e}}$ Not detected.

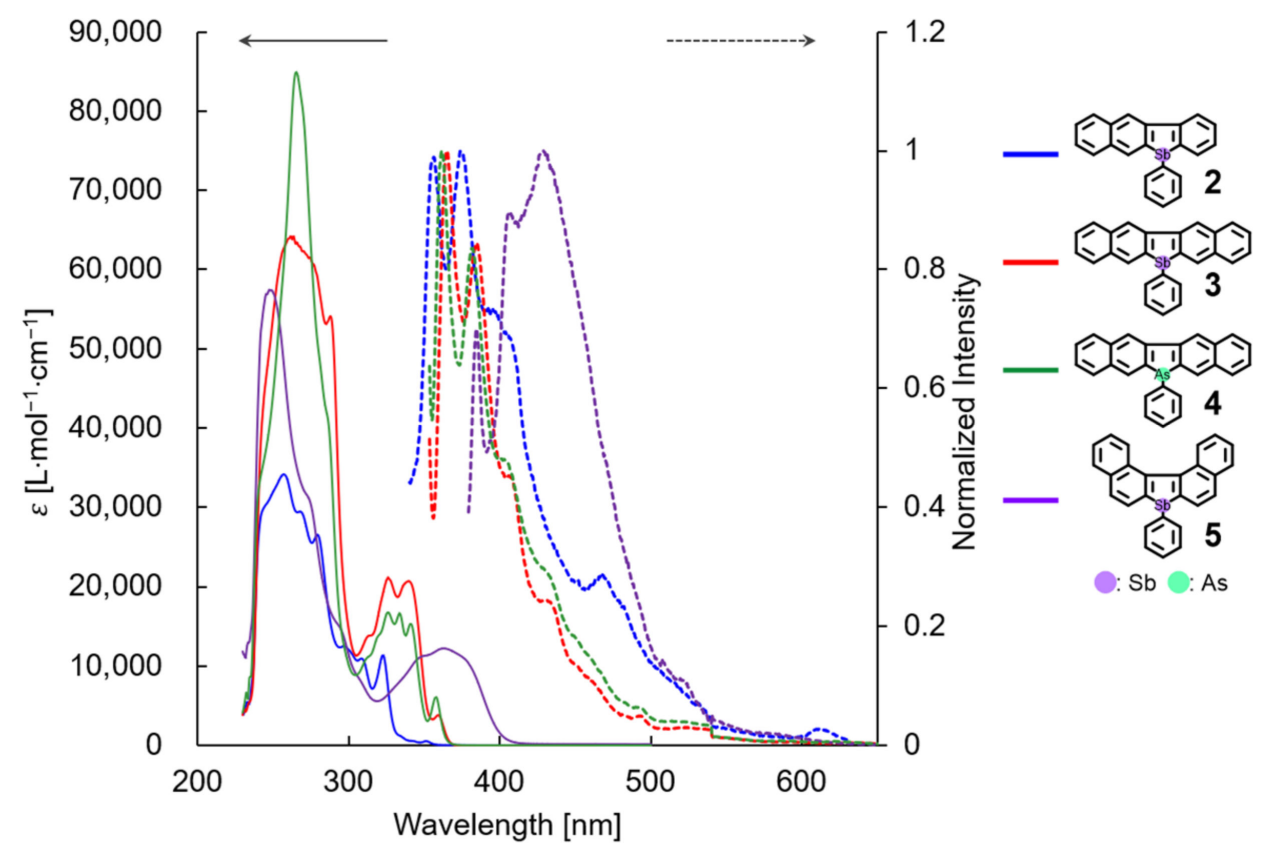

Figure 3. Absorption (solid lines) and normalized emission (dashed lines) spectra at room temperature of stiboles 2 (blue), $\mathbf{3}$ (red), $\mathbf{4}$ (green) and $\mathbf{5}$ (purple) in $\mathrm{CHCl}_{3}$. Excitation at 320 (for 2), 340 (for 3 and 4), and $360 \mathrm{~nm}$ (for 5). 


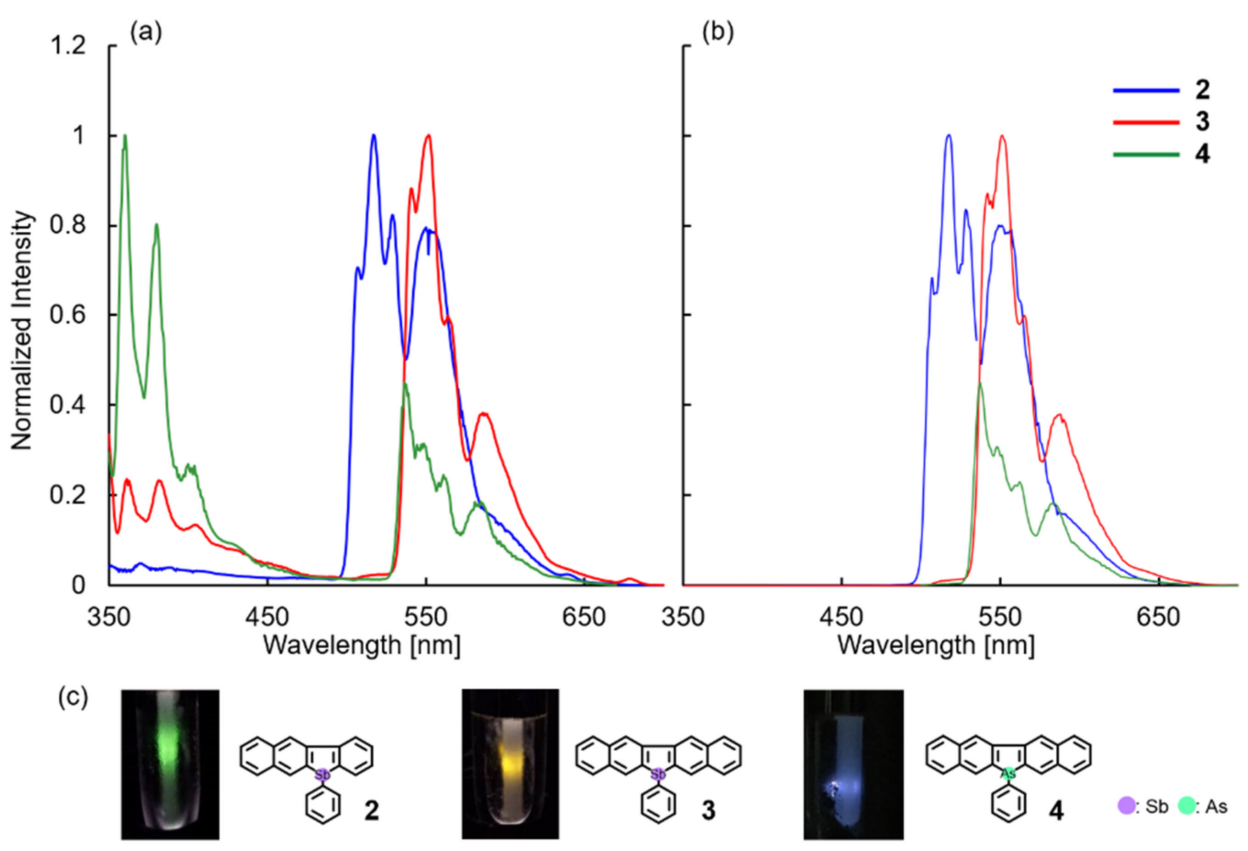

Figure 4. (a) Normalized fluorescence and (b) phosphorescence spectra of 2 (blue), 3 (red), and 4 (green) in $\mathrm{CHCl}_{3}$ at $77 \mathrm{~K}$. Excitation at 320 (for 2) and $340 \mathrm{~nm}$ (for 3 and 4). Gating parameters for phosphorescence (delay, $27 \mathrm{~ms}$ ). (c) Photo of the solution of $\mathbf{2 - 4}$ in $\mathrm{CHCl}_{3}$ at $77 \mathrm{~K}$ under UV irradiation (320 nm for 2 and $340 \mathrm{~nm}$ for 3 and 4).

\section{Materials and Methods}

\subsection{General Information}

Melting points were taken on a Yanagimoto micro melting point hot-stage apparatus (MP-S3) and are not corrected. ${ }^{1} \mathrm{H}-\mathrm{NMR}(400 \mathrm{MHz}$, TMS: $\delta=0.00 \mathrm{ppm}$ as an internal standard) and ${ }^{13} \mathrm{C}-\mathrm{NMR}\left(100 \mathrm{MHz}, \mathrm{CDCl}_{3}: \delta=77.00 \mathrm{ppm}\right.$ as an internal standard) spectra were recorded on JEOL ECZ-400S spectrometer (JEOL Ltd., Tokyo, Japan) in $\mathrm{CDCl}_{3}$. ESI mass spectra were measured on an Agilent Technologies $6230 \mathrm{LC} / \mathrm{TOF}$ mass spectrometer (Agilent Technologies Japan, Ltd., Tokyo, Japan). IR spectra were recorded on a SHIMADZU FTIR-8400S spectrometer (SHIMADZU CORPORATION, Kyoto, Japan) and are reported in frequency of absorption $\left(\mathrm{cm}^{-1}\right)$. Only selected IR peaks are reported. UV/Vis spectra were recorded at room temperature on a HITACHI U-2800A spectrophotometer (Hitachi High-Tech Corporation, Tokyo, Japan) $\left(2: C=5.2 \times 10^{-5}, 3: C=4.7 \times 10^{-5}\right.$,

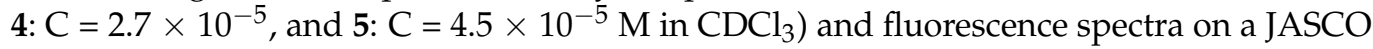
FP-8300 luminescence spectrometer (JASCO Corporation, Tokyo, Japan) $\left(2: \mathrm{C}=2.1 \times 10^{-6}\right.$, 3: $\mathrm{C}=1.6 \times 10^{-6}, 4: \mathrm{C}=1.9 \times 10^{-6}$, and 5: $\mathrm{C}=2.8 \times 10^{-6} \mathrm{M}$ in $\left.\mathrm{CDCl}_{3}\right)$. All chromatographic separations were accomplished with Silica Gel 60N (Kanto Chemical Co., Inc., Tokyo, Japan). Thin-layer chromatography (TLC) was performed with Macherey-Nagel Pre-coated TLC plates Sil G25 UV 254 . Most of the reagents were used without further purification unless otherwise specified.

Known cyclization precursors $\mathbf{1 b}$ [32] and 1c [31] were prepared according to the reported procedures, and spectroscopic data are in accordance with the literature.

\subsection{Preparation and Characterization of Novel Compounds}

\subsubsection{2-Bromo-3-(2-bromophenyl)naphthalene (1a)}

A solution of 2-bromoiodobenzene $(2.83 \mathrm{~g}, 10 \mathrm{mmol})$ and tetrakis(triphenylphosphine)palladium(0) (1.04 g, $0.90 \mathrm{mmol}, 9 \mathrm{~mol} \%)$ in dry toluene $(80 \mathrm{~mL})$ were stirred for $1 \mathrm{~h}$ under Ar atmosphere. Then a solution of 3-bromo-2-naphthylboronic acid $(3.76 \mathrm{~g}, 15 \mathrm{mmol}$, 1.5 eq.) in dry ethanol and sodium thiosulfate aqueous $(2.45 \mathrm{M}, 25 \mathrm{~mL}, 60 \mathrm{mmol}, 6$ eq.) were added to the reaction mixture, and reflux at $85^{\circ} \mathrm{C}$. After $2.5 \mathrm{~h}$, the reaction mixture 
was diluted with $\mathrm{CH}_{2} \mathrm{Cl}_{2}(150 \mathrm{~mL})$ and water $(100 \mathrm{~mL})$ at $0{ }^{\circ} \mathrm{C}$. The phases were separated and the aqueous layer was extracted with $\mathrm{CH}_{2} \mathrm{Cl}_{2}(50 \mathrm{~mL} \times 3)$. The combined organic layer was washed with sat. sodium thiosulfate aqueous $(30 \mathrm{~mL} \times 3)$, dried over anhydrous magnesium sulfate, filtered, and concentrated under reduced pressure. The residue was purified by column chromatography using $n$-hexane as eluent to give 1 a as a colorless plate (3.36 g, 93\%),m.p.109-112 ${ }^{\circ} \mathrm{C}$ (benzene/ethanol). ${ }^{1} \mathrm{H}-\mathrm{NMR}\left(400 \mathrm{MHz}, \mathrm{CDCl}_{3}\right) \delta: 8.18$ (s, 1H), 7.83-7.79 (m, 2H), $7.72(\mathrm{~s}, 1 \mathrm{H}), 7.69(\mathrm{~d}, J=8.3 \mathrm{~Hz}, 1 \mathrm{H}), 7.56-7.49(\mathrm{~m}, 2 \mathrm{H}), 7.40(\mathrm{t}$, $J=7.3 \mathrm{~Hz}, 1 \mathrm{H}), 7.33-7.24(\mathrm{~m}, 2 \mathrm{H}) .{ }^{13} \mathrm{C}-\mathrm{NMR}\left(100 \mathrm{MHz}, \mathrm{CDCl}_{3}\right) \delta: 142.0(\mathrm{C}), 139.5(\mathrm{C}), 133.8$ (C), $132.5(\mathrm{CH}), 132.0(\mathrm{C}), 131.2(\mathrm{CH}), 131.0(\mathrm{CH}), 129.8(\mathrm{CH}), 129.4(\mathrm{CH}), 128.0(\mathrm{CH}), 127.10$ (CH), $127.05(\mathrm{CH}), 126.8(\mathrm{CH}), 126.6(\mathrm{CH}), 124.0(\mathrm{C}), 121.3(\mathrm{C})$. FTIR (KBr): 3051, 1423, 1424, 876, $746 \mathrm{~cm}^{-1}$. LRMS (EI) m/z: $362\left(\left[\mathrm{M}^{+}, 99 \%\right), 283(30 \%), 202(100 \%), 83\right.$ (73\%). HRMS: $m / z[\mathrm{M}]^{+}$calculated for $\mathrm{C}_{16} \mathrm{H}_{10} \mathrm{Br}_{2}$ : 361.9129. found: 361.9131 .

\subsubsection{5-Phenylbenzo[ $[b]$ naphtho[2,3- $d]$ stibole (2)}

A solution of $n$-BuLi (1.61 M solution in hexane, $4.5 \mathrm{~mL}, 7.2 \mathrm{mmol}, 2.1$ eq.) was added dropwise to a solution of 2-bromo-3-(2-bromophenyl)naphthalene (1a) $(1.24 \mathrm{~g}, 3.4 \mathrm{mmol})$ in dry THF $(40 \mathrm{~mL})$ at $-78^{\circ} \mathrm{C}$ under Ar atmosphere. After $1.5 \mathrm{~h}$, dibromo(phenyl)stibane ( $1.60 \mathrm{~g}, 4.5 \mathrm{mmol}, 1.3 \mathrm{eq}$.) was added to the reaction mixture and the resulting mixture was stirred for $1 \mathrm{~h}$. The reaction mixture was diluted with $\mathrm{CH}_{2} \mathrm{Cl}_{2}(40 \mathrm{~mL})$ and water $(40 \mathrm{~mL})$ at $0{ }^{\circ} \mathrm{C}$. The phases were separated, and the aqueous layer was extracted with $\mathrm{CH}_{2} \mathrm{Cl}_{2}$ $(50 \mathrm{~mL} \times 3)$. The combined organic layer was washed with water $(30 \mathrm{~mL} \times 3)$, dried over anhydrous magnesium sulfate, filtered, and concentrated under reduced pressure. The residue was purified by column chromatography using $n$-hexane $/ \mathrm{CH}_{2} \mathrm{Cl}_{2}(10: 1)$ as eluent to give 2 as a colorless needle $(621 \mathrm{mg}, 46 \%)$. m.p. $118-120{ }^{\circ} \mathrm{C}\left(\mathrm{CH}_{2} \mathrm{Cl}_{2} / n\right.$-hexane). ${ }^{1} \mathrm{H}-\mathrm{NMR}\left(400 \mathrm{MHz} \mathrm{CDCl}_{3}\right) \delta: 8.33(\mathrm{~s}, 1 \mathrm{H}), 8.18(\mathrm{~s}, 1 \mathrm{H}), 8.10(\mathrm{~d}, J=7.9 \mathrm{~Hz}, 1 \mathrm{H}), 7.86(\mathrm{~d}$, $J=7.6 \mathrm{~Hz}, 1 \mathrm{H}), 7.75(\mathrm{t}, J=8.6 \mathrm{~Hz}, 2 \mathrm{H}), 7.49-7.42(\mathrm{~m}, 3 \mathrm{H}), 7.34-7.29(\mathrm{~m}, 3 \mathrm{H}), 7.17-7.10(\mathrm{~m}$, 3H). ${ }^{13} \mathrm{C}-\mathrm{NMR}\left(100 \mathrm{MHz}, \mathrm{CDCl}_{3}\right) \delta: 149.7$ (C), $147.4(\mathrm{C}), 145.1$ (C), 142.7 (C), 138.7 (C), $135.6(\mathrm{CH}), 135.4(\mathrm{CH}), 135.2(\mathrm{CH}), 133.6(\mathrm{C}), 133.3(\mathrm{C}), 129.0(\mathrm{CH}), 128.7(\mathrm{CH}), 128.49(\mathrm{CH})$, $128.45(\mathrm{CH}), 128.1(\mathrm{CH}), 127.5(\mathrm{CH}), 126.5(\mathrm{CH}), 126.0(\mathrm{CH}), 123.8(\mathrm{CH}), 121.7(\mathrm{CH})$. FTIR (KBr): 3048, 1429, 880, 772, 733, $692 \mathrm{~cm}^{-1}$. LRMS (EI) m/z: 400 ([M] $\left.]^{+}, 100 \%\right), 323(50 \%), 279$ (73\%), 202 (55\%). HRMS: $m / z[\mathrm{M}]^{+}$calculated for $\mathrm{C}_{22} \mathrm{H}_{13} \mathrm{Sb}$ : 400.0212. Found: 400.0209.

\subsubsection{6-Phenyldinaphtho[2,3- $\left.b, 2^{\prime}, 3^{\prime}-d\right]$ stibole (3)}

A solution of $n$-BuLi (1.54 M solution in hexane, $3 \mathrm{~mL}, 4.8 \mathrm{mmol}, 2.4$ eq.) was added dropwise to a solution of 3,3'-dibromo-2,2'-binaphthyl (1b) (823 mg, $2.0 \mathrm{mmol})$ in dry THF (30 mL) at $-78{ }^{\circ} \mathrm{C}$ under Ar atmosphere. After $1 \mathrm{~h}$, dibromo(phenyl)stibane (1.07 $\mathrm{g}$, $3.0 \mathrm{mmol}, 1.5 \mathrm{eq}$.) was added to the reaction mixture and the resulting mixture was stirred for $1 \mathrm{~h}$. The reaction mixture was diluted with $\mathrm{CH}_{2} \mathrm{Cl}_{2}(30 \mathrm{~mL})$ and water $(30 \mathrm{~mL})$ at $0{ }^{\circ} \mathrm{C}$. The phases were separated, and the aqueous layer was extracted with $\mathrm{CH}_{2} \mathrm{Cl}_{2}(30 \mathrm{~mL} \times 3)$. The combined organic layer was washed with water $(30 \mathrm{~mL} \times 3)$, dried over anhydrous magnesium sulfate, filtered, and concentrated under reduced pressure. The residue was purified by column chromatography using $n$-hexane $/ \mathrm{CH}_{2} \mathrm{Cl}_{2}(10: 1)$ as eluent to give 3 as a colorless needle (483 mg, 54\%). m.p. $227-229.5{ }^{\circ} \mathrm{C}$ (benzene $/ n$-hexane). ${ }^{1} \mathrm{H}-\mathrm{NMR}$ $\left(400 \mathrm{MHz} \mathrm{CDCl}_{3}\right) \delta: 8.56(\mathrm{~s}, 2 \mathrm{H}), 8.24(\mathrm{~s}, 2 \mathrm{H}), 7.96(\mathrm{~d}, J=7.9 \mathrm{~Hz}, 2 \mathrm{H}), 7.80(\mathrm{~d}, J=7.6 \mathrm{~Hz}$, 2H), 7.53-7.43 (m, 4H) $7.35(\mathrm{~d}, J=7.9 \mathrm{~Hz}, 2 \mathrm{H}), 7.17-7.09(\mathrm{~m}, 3 \mathrm{H}) .{ }^{13} \mathrm{C}-\mathrm{NMR}(100 \mathrm{MHz}$, $\left.\mathrm{CDCl}_{3}\right) \delta: 146.9(\mathrm{C}), 142.8(\mathrm{C}), 139.3(\mathrm{C}), 135.7(\mathrm{CH}), 135.1(\mathrm{CH}), 133.8(\mathrm{C}), 133.6(\mathrm{C}), 128.7$ $(\mathrm{CH}), 128.5(\mathrm{CH}), 128.3(\mathrm{CH}), 127.6(\mathrm{CH}), 126.6(\mathrm{CH}), 126.1(\mathrm{CH}), 122.1(\mathrm{CH})$. FTIR $(\mathrm{KBr})$ : $3046,876,745,731,694 \mathrm{~cm}^{-1}$. LRMS (EI) $\mathrm{m} / z: 450\left([\mathrm{M}]^{+}, 100 \%\right), 373(45 \%), 252(68 \%), 149$ (28\%). HRMS: $m / z[\mathrm{M}]^{+}$calculated for $\mathrm{C}_{26} \mathrm{H}_{17} \mathrm{Sb}: 450.0368$. Found: 450.0364 .

\subsubsection{6-Phenyldinaphtho[2,3- $\left.b, 2^{\prime}, 3^{\prime}-d\right]$ arsole (4)}

A solution of $n$-BuLi (1.60 M solution in hexane, $2.3 \mathrm{~mL}, 3.6 \mathrm{mmol}, 2.4$ eq.) was added dropwise to a solution of 3,3'-dibromo-2,2'-binaphthyl (1b) $(618 \mathrm{mg}, 1.5 \mathrm{mmol})$ in dry THF $(24 \mathrm{~mL})$ at $-78^{\circ} \mathrm{C}$ under Ar atmosphere. After $20 \mathrm{~min}$, dichloro(phenyl)arisine $(0.5 \mathrm{~mL}$, 
$3.6 \mathrm{mmol}, 2.4$ eq.) was added to the reaction mixture and the resulting mixture was stirred for $30 \mathrm{~min}$. The reaction mixture was diluted with $\mathrm{CH}_{2} \mathrm{Cl}_{2}(45 \mathrm{~mL})$ and water $(45 \mathrm{~mL})$ at $0{ }^{\circ} \mathrm{C}$. The phases were separated, and the aqueous layer was extracted with $\mathrm{CH}_{2} \mathrm{Cl}_{2}$ $(30 \mathrm{~mL} \times 3)$. The combined organic layer was washed with water $(30 \mathrm{~mL} \times 3)$, dried over anhydrous magnesium sulfate, filtered, and concentrated under reduced pressure. The residue was purified by column chromatography using $n$-hexane $/ \mathrm{CH}_{2} \mathrm{Cl}_{2}$ (4:1) as eluent to give 4 as a colorless prism (333 mg, 55\%). m.p. $209-211{ }^{\circ} \mathrm{C}\left(\mathrm{CH}_{2} \mathrm{Cl}_{2} / n\right.$-hexane). ${ }^{1} \mathrm{H}-\mathrm{NMR}$ $\left(400 \mathrm{MHz}_{\mathrm{CDCl}}\right) \delta: 8.48(\mathrm{~s}, 2 \mathrm{H}), 8.19(\mathrm{~s}, 2 \mathrm{H}), 7.93(\mathrm{~d}, J=7.8 \mathrm{~Hz}, 2 \mathrm{H}), 7.79(\mathrm{~d}, J=8.3 \mathrm{~Hz}$, 2H), 7.51-7.43 (m, 4H) $7.30(\mathrm{dd}, J=7.3,2.0 \mathrm{~Hz}, 2 \mathrm{H}), 7.17-7.10(\mathrm{~m}, 3 \mathrm{H}) .{ }^{13} \mathrm{C}-\mathrm{NMR}(100 \mathrm{MHz}$, $\left.\mathrm{CDCl}_{3}\right) \delta: 143.5(\mathrm{C}), 142.8(\mathrm{C}), 141.5(\mathrm{C}), 133.8(\mathrm{C}), 133.6(\mathrm{C}), 132.0(\mathrm{CH}), 131.6(\mathrm{CH}), 128.7$ $(\mathrm{CH}), 128.5(\mathrm{CH}), 128.4(\mathrm{CH}), 127.8(\mathrm{CH}), 126.5(\mathrm{CH}), 126.1(\mathrm{CH}), 120.9(\mathrm{CH})$. FTIR $(\mathrm{KBr})$ : 3046, 874, 745, $737 \mathrm{~cm}^{-1}$. LRMS (EI) $\mathrm{m} / z$ : 404 ([M] $\left.]^{+}, 43 \%\right), 327(40 \%), 254(63 \%), 83(100 \%)$. HRMS: $m / z[\mathrm{M}]^{+}$calculated for $\mathrm{C}_{26} \mathrm{H}_{17} \mathrm{Sb}: 404.0546$. Found: 404.0544 .

\subsubsection{7-Phenyldinaphtho[2,1- $\left.b, 1^{\prime}, 2^{\prime}-d\right]$ stibole (5)}

A solution of 2,2'-dibromo-1,1'-binaphthyl (1c) $(827 \mathrm{mg}, 2.0 \mathrm{mmol})$ in dry THF $(45 \mathrm{~mL})$ was added dropwise to a solution of $t$-BuLi $(1.60 \mathrm{M}$ solution in hexane, $6.2 \mathrm{~mL}$, $10 \mathrm{mmol}, 5$ eq. $)$ in dry THF $(20 \mathrm{~mL})$ at $-78^{\circ} \mathrm{C}$ under Ar atmosphere. After $10 \mathrm{~min}$, dibromo(phenyl)stibane $(1.07 \mathrm{~g}, 3.0 \mathrm{mmol}, 1.5 \mathrm{eq}$.) was added to the reaction mixture and the resulting mixture was stirred for $1 \mathrm{~h}$. The reaction mixture was diluted with $\mathrm{CH}_{2} \mathrm{Cl}_{2}(30 \mathrm{~mL})$ and water $(30 \mathrm{~mL})$ at $0{ }^{\circ} \mathrm{C}$. The phases were separated and the aqueous layer was extracted with $\mathrm{CH}_{2} \mathrm{Cl}_{2}(30 \mathrm{~mL} \times 3)$. The combined organic layer was washed with water $(30 \mathrm{~mL} \times 3)$, dried over anhydrous magnesium sulfate, filtered, and concentrated under reduced pressure. The residue was purified by column chromatography using $n$-hexane $/ \mathrm{CH}_{2} \mathrm{Cl}_{2}(10: 1)$ as eluent to give 5 as a colorless needle $(220 \mathrm{mg}, 24 \%)$. m.p. $142-143.5{ }^{\circ} \mathrm{C}\left(\mathrm{Et}_{2} \mathrm{O} / \mathrm{n}\right.$-hexane $)$. ${ }^{1} \mathrm{H}-\mathrm{NMR}\left(400 \mathrm{MHz}, \mathrm{CDCl}_{3}\right) \delta: 7.96-7.90(\mathrm{~m}, 5 \mathrm{H}), 7.86(\mathrm{dd}, J=7.8,2.4 \mathrm{~Hz}, 2 \mathrm{H}), 7.85(\mathrm{~d}$, $J=7.8 \mathrm{~Hz}, 1 \mathrm{H}), 7.51-7.47(\mathrm{~m}, 2 \mathrm{H}), 7.34(\mathrm{tt}, J=9.5,2.0 \mathrm{~Hz}, 2 \mathrm{H}) 7.25(\mathrm{dd}, J=7.7,1.5 \mathrm{~Hz}, 2 \mathrm{H})$, $7.15(\mathrm{tt}, J=7.8,1.5 \mathrm{~Hz}, 1 \mathrm{H}), 7.09(\mathrm{t}, J=7.8 \mathrm{~Hz}, 2 \mathrm{H}) .{ }^{13} \mathrm{C}-\mathrm{NMR}\left(100 \mathrm{MHz}, \mathrm{CDCl}_{3}\right) \delta: 149.0(\mathrm{C})$, $148.1(\mathrm{C}), 145.0(\mathrm{C}), 144.0(\mathrm{C}), 138.3(\mathrm{C}), 135.5(\mathrm{CH}), 134.7(\mathrm{C}), 134.3(\mathrm{C}), 131.9(\mathrm{C}), 131.7(\mathrm{C})$, $131.6(\mathrm{CH}), 130.6(\mathrm{CH}), 128.8(\mathrm{CH}), 128.7(\mathrm{CH}), 128.5(\mathrm{CH}), 128.3(\mathrm{CH}), 128.2(\mathrm{CH}), 128.1$ $(\mathrm{CH}), 128.0(\mathrm{CH}), 127.8(\mathrm{CH}), 125.7(\mathrm{CH}), 125.6(\mathrm{CH}), 124.53(\mathrm{CH}), 124.52(\mathrm{CH})$. FTIR $(\mathrm{KBr})$ : 3046, 1431, 812, 750, $729 \mathrm{~cm}^{-1}$. LRMS (EI) m/z: 450 ([M] $\left.{ }^{+}, 99 \%\right), 371(30 \%), 329(100 \%), 252$ (60\%). HRMS: $m / z[\mathrm{M}]^{+}$calculated for $\mathrm{C}_{26} \mathrm{H}_{17} \mathrm{Sb}$ : 450.0368 . Found: 450.0371 .

\subsection{Single Crystal X-ray Diffraction Experiment}

\subsubsection{Compound 3}

The colorless plate crystal $\left(0.100 \times 0.070 \times 0.020 \mathrm{~mm}^{3}\right)$, obtained from methanol/ dichloromethane, was immersed in Paraton- $\mathrm{N}$ oil and placed in the $\mathrm{N}_{2}$ cold stream at $100 \mathrm{~K}$. The diffraction experiment was performed in a Bruker APEX II system (Bruker, Kanagawa, Japan) (APEX II CCD detector, MoK $\alpha: \lambda=0.71073 \AA$ A). Absorption correction was performed by an empirical method implemented in SADABS [37]. Structure solution and refinement were performed by using SHELXS-2014/7 and SHELXL-2014/7 [38].

$\mathrm{C}_{26} \mathrm{H}_{17} \mathrm{Sb}, \mathrm{Mr}=451.14$; orthorhombic, space group $P 2{ }_{1} 2{ }_{1} 21, \mathrm{Z}=4, D_{\text {calc }}=1.617 \mathrm{~g} \cdot \mathrm{cm}^{-3}$, $a=5.1377(17), b=12.092(4), c=29.834(10) \AA, V=1853.5(11) \AA^{3}, 16,845$ measured and 3415 independent $[I>2 \sigma(I)]$ reflections, 144 parameters, final $R_{1}=0.0383, w R_{2}=0.0744$, $S=1.081[I>2 \sigma(I)]$. CCDC 2041167 .

All non-hydrogen atoms were refined anisotropically. The hydrogen atoms were refined isotropically on the calculated positions using a riding model (AFIX 43) with Uiso values constrained to $1.2 / 1.5$ Ueq of their parent atoms.

\subsubsection{Compound 5}

The colorless prismatic crystal $\left(0.300 \times 0.300 \times 0.150 \mathrm{~mm}^{3}\right)$, obtained from ether/ hexane, was immersed in Paraton- $\mathrm{N}$ oil and placed in the $\mathrm{N}_{2}$ cold stream at $100 \mathrm{~K}$. The diffraction experiment was performed in a Bruker APEX II system (Bruker, Kanagawa, 
Japan) (APEX II CCD detector, MoK $\alpha: \lambda=0.71073 \AA$ ). Absorption correction was performed by an empirical method implemented in SADABS [37]. Structure solution and refinement were performed by using SHELXS-2014/7 and SHELXL-2014/7 [38].

$\mathrm{C}_{26} \mathrm{H}_{17} \mathrm{Sb}, M \mathrm{r}=451.14$; orthorhombic, space group $P 2_{1} 2_{1} 2_{1}, \mathrm{Z}=4, D_{\text {calc }}=1.563 \mathrm{~g} \cdot \mathrm{cm}^{-3}$, $a=8.5914(15), b=9.9720(17), c=22.374(4) \AA, V=1916.9(6) \AA^{3}, 17,554$ measured and 3498 independent $[I>2 \sigma(I)]$ reflections, 244 parameters, final $R_{1}=0.0114, w R_{2}=0.0311$, $S=0.985[I>2 \sigma(I)]$. CCDC 2041187.

All non-hydrogen atoms were refined anisotropically. The hydrogen atoms were refined isotropically on the calculated positions using a riding model (AFIX 43) with Uiso values onstrained to $1.2 / 1.5$ Ueq of their parent atoms.

\section{Conclusions}

In this study, penta- and tetracyclic stiboles and a pentacyclic arsole were synthesized using a double lithiation method. The NMR spectra revealed that linear pentacyclic compounds 3 and $\mathbf{4}$ had highly symmetric structures in solution. In contrast, the two naphthalene rings in curved pentacyclic stibole $\mathbf{5}$ were chemically nonequivalent. X-ray analysis revealed that the naphthalene wings of linear stibole 3 were slightly bent and packing structure of 3 formed $\pi-\pi$ stacking. In the case of curved stibole 5, prepared as a racemate, spontaneous resolution occurred during crystallization, and the single crystal of compound $\mathbf{5}$ contained only $\mathrm{M}$ helical molecules. This is the first example of spontaneous resolution for a stibole derivative. All compounds displayed very weak or no emissions at room temperature or in the solid state. In contrast, linear compounds $\mathbf{2 - 4}$ showed clear phosphorescence emissions in the $\mathrm{CHCl}_{3}$ frozen matrix at $77 \mathrm{~K}$ under aerobic conditions. Further investigations are underway, including synthesize of other isomers by the different in a position of fused benzene ring and the evaluation of the physicochemical properties, such as fluorescence, phosphorescence and redox potential, by theoretical and electrochemical studies.

Supplementary Materials: The following are available online, Figure S1: Fluorescence and phosphorescence spectra of compound $5 .{ }^{1} \mathrm{H}$ - and ${ }^{13} \mathrm{C}-\mathrm{NMR}$ spectra are available online. The crystal structures have been deposited to the CCDC with the numbers 2041167 and 2041187, and CIF files are also provided as Supplementary Materials.

Author Contributions: M.M. and S.Y. designed chemical synthesis, analyzed results, and wrote the manuscript. Y.M. (Yuki Matsuhashi), M.K. (Masato Kawakubo), and Y.M. (Yuki Murata) performed chemical synthesis experiments and analyzed results and wrote the manuscript. T.H., M.K. (Masatoshi Kawahata) and K.Y. performed single-crystal X-ray diffraction analysis and wrote the manuscript. All authors have read and agreed to the published version of the manuscript.

Funding: This research was supported by JSPS KAKENHI (Grant Number JP19K07005, S. Y.).

Data Availability Statement: The data presented in this study are available in this article.

Conflicts of Interest: The authors declare no conflict of interest.

Sample Availability: Not available.

\section{References}

1. Baumgartner, T.; Jäkle, F. (Eds.) Main Group Strategies towards Functional Hybrid Materials; John Wiley \& Sons Ltd.: Chichester, UK, 2018.

2. Hissler, M.; Dyer, P.W.; Réau, R. Linear organic $\pi$-conjugated systems featuring the heavy Group 14 and 15 elements. Coord. Chem. Rev. 2003, 244, 1-44. [CrossRef]

3. Baumgartner, T.; Réau, R. Organophosphorus $\pi$-conjugated materials. Chem. Rev. 2006, 106, 4681-4727. [CrossRef] [PubMed]

4. Hobbs, M.G.; Baumgartner, T. Recent developments in phosphole-containing oligo- and polythiophene materials. Eur. J. Inorg. Chem. 2007, 3611-3628. [CrossRef]

5. Zagidullin, A.A.; Bezkishko, I.A.; Miluykov, V.A.; Sinyashin, O.G. Phospholes-development and recent advances. Mendeleev Commun. 2013, 23, 117-130. [CrossRef]

6. Duffy, M.P.; Delaunay, W.; Bouit, P.-A.; Hissler, M. $\pi$-Conjugated phospholes and their incorporation into devices: Components with a great deal of potential. Chem. Soc. Rev. 2016, 45, 5296-5310. [CrossRef] 
7. Ishijima, K.; Tanaka, S.; Imoto, H.; Naka, K. 2-Arylbenzo[b]arsoles: An experimental and computational study on the relationship between structural and photophysical properties. Dalton Trans. 2020, 49, 15612-15621. [CrossRef]

8. Fujii, T.; Tanaka, S.; Hayashi, S.; Imoto, H.; Naka, K. Dipyridinoarsole: A new class of stable and modifiable heteroatom-bridged bipyridines. Chem. Commun. 2020, 56, 6035-6038. [CrossRef]

9. Urushizaki, A.; Yumura, T.; Kitagawa, Y.; Hasegawa, Y.; Imoto, H.; Naka, K. Dithieno[3,4-b:3' $4^{\prime}$-d] $]$ arsole: A novel class of hetero[5]radialenes. Eur. J. Org. Chem. 2020, 2020, 3965-3970. [CrossRef]

10. Tanaka, S.; Enoki, T.; Imoto, H.; Ooyama, Y.; Ohshita, J.; Kato, T.; Naka, K. Highly efficient singlet oxygen generation and high oxidation resistance enhanced by arsole-polymer-based photosensitizer: Application as a recyclable photooxidation catalyst. Macromolecules 2020, 53, 2006-2013. [CrossRef]

11. Imoto, H.; Naka, K. The Dawn of functional organoarsenic chemistry. Chem. Eur. J. 2019, 25, 1883-1894. [CrossRef]

12. Rivard, E. Tellurophenes and their emergence as building blocks for polymeric and light-emitting materials. Chem. Lett. 2015, 44, 730-736. [CrossRef]

13. Parke, S.M.; Narreto, M.A.B.; Hupf, E.; McDonald, R.; Ferguson, M.J.; Hegmann, F.A.; Rivard, E. Understanding the origin of phosphorescence in bismoles: A synthetic and computational study. Inorg. Chem. 2018, 57, 7536-7549. [CrossRef] [PubMed]

14. Parke, S.M.; Hupf, E.; Matharu, G.K.; de Aguiar, I.; Xu, L.; Yu, H.; Boone, M.P.; de Souza, G.L.C.; McDonald, R.; Ferguson, M.J.; et al. Aerobic solid state red phosphorescence from benzobismole monomers and patternable self-assembled block copolymers. Angew. Chem. Int. Ed. 2018, 57, 14841-14846. [CrossRef] [PubMed]

15. Jiang, M.; Guo, J.; Liu, B.; Tan, Q.; Xu, B. Synthesis of tellurium-containing $\pi$-extended aromatics with room-temperature phosphorescence. Org. Lett. 2019, 21, 8328-8333. [CrossRef] [PubMed]

16. Hupf, E.; Tsuchiya, Y.; Moffat, W.; Xu, L.; Hirai, M.; Zhou, Y.; Ferguson, M.J.; McDonald, R.; Murai, T.; He, G.; et al. A modular approach to phosphorescent $\pi$-extended heteroacenes. Inorg. Chem. 2019, 58, 13323-13336. [CrossRef] [PubMed]

17. Herwaldt, B.L.; Berman, J.D. Recommendations for treating Leishmaniasis with sodium stibogluconate (Pentostam) and review of pertinent clinical studies. Am. J. Trop. Med. Hyg. 1992, 46, 296-306. [CrossRef]

18. Fujiwara, Y.; Mitani, M.; Yasuike, S.; Kurita, J.; Kaji, T. An organobismuth compound that exhibits selective cytotoxicity to vascular endothelial cells in vitro. J. Health Sci. 2005, 51, 333-340. [CrossRef]

19. Kohri, K.; Yoshida, E.; Yasuike, S.; Fujie, T.; Yamamoto, C.; Kaji, T. The cytotoxicity of organobismuth compounds with certain molecular structures can be diminished by replacing the bismuth atom with an antimony atom in the molecules. J. Toxicol. Sci. 2015, 40, 321-327. [CrossRef]

20. Hara, T.; Nakano, S.; Kitamura, Y.; Yamamoto, C.; Yasuike, S.; Kaji, T. Intracellular accumulation-independent cytotoxicity of pentavalent organoantimony compounds in cultured vascular endothelial cells. J. Toxicol. Sci. 2019, 44, 845-848. [CrossRef]

21. Sum, H. (Ed.) Biological Chemistry of Aresenic, Antimony and Bismuth; Jhon Wiley \& Sons Ltd.: Chichester, UK, 2011.

22. Ashe, A.J.; Drone, F.J. Synthesis of 1-phenylarsole and 1-phenylstibole. Organometallics 1985, 4, 1478-1480. [CrossRef]

23. Kurita, J.; Ishii, M.; Yasuike, S.; Tsuchiya, T. A versatile synthetic route to 1-benzometalloles involving the first examples of several C-unsubstituted benzometalloles. J. Chem. Soc. Chem. Commun. 1993, 1309-1310. [CrossRef]

24. Kurita, J.; Ishii, M.; Yasuike, S.; Tsuchiya, T. Synthesis of 1-benzometalloles containing group 14, 15, and 16 heavier elements via a common dilithiostyrene intermediate. Chem. Pharm. Bull 1994, 42, 1437-1441. [CrossRef]

25. Heinekey, D.M.; Millar, I.T. The synthesis of 9-alkyl- or 9-aryl-9-arsafluorenes or -9-stibiafluorenes. J. Chem. Soc. 1959, 3101-3102.

26. Kurita, J.; Usuda, F.; Yasuike, S.; Tsuchiya, T.; Tsuda, Y.; Kiuchi, F.; Hosoi, S. Resolution of racemic Sb-chiral stibindoles using an optically active ortho-palladated benzylamine derivative, via their diastereomeric complexes. Chem. Commun. 2000, 191-192. [CrossRef]

27. Christianson, A.M.; Rivard, E.; Gabbaï, F.P. $1 \lambda^{5}$-stibaindoles as lewis acidic, $\pi$-conjugated, fluoride anion responsive platforms. Organometallics 2017, 36, 2670-2676. [CrossRef]

28. Christianson, A.M.; Gabbaï, F.P. A lewis acidic, $\pi$-conjugated stibaindole with a colorimetric response to anion binding at $\mathrm{Sb}(\mathrm{III})$. Organometallics 2017, 36, 3013-3015. [CrossRef]

29. Ohshita, J.; Fujita, R.; Tanaka, D.; Ooyama, Y.; Kobayashi, N.; Higashimura, H.; Yamamoto, Y. Synthesis and optical properties of dithienostiboles. Chem. Lett. 2012, 41, 1002-1003. [CrossRef]

30. Ohshita, J.; Yamaji, K.; Ooyama, Y.; Adachi, Y.; Nakamura, M.; Watase, S. Synthesis, properties, and complex formation of antimony- and bismuth-bridged bipyridyls. Organometallics 2019, 38, 1516-1523. [CrossRef]

31. Yasuike, S.; Iida, T.; Yamaguchi, K.; Seki, H.; Kurita, J. Synthesis, molecular structure and fluxional behavior of (R)-7-ptolyldinaphtho[2,1-b; $\left.1^{\prime}, 2^{\prime}-d\right]$ stibole: The first isolated example of optically active group 15 dinaphthoheteroles. Tetrahedron Lett. 2001, 42, 441-444. [CrossRef]

32. Matsumura, M.; Kawahata, M.; Muranaka, A.; Hiraiwa, M.; Yamaguchi, K.; Uchiyama, M.; Yasuike, S. Efficient synthesis, structural Characterization, and optical properties of $6 \mathrm{H}$-dibenzo[b,h]carbazole and its derivatives. Eur. J. Org. Chem. 2019, 3788-3793. [CrossRef]

33. Jacques, J.; Collet, A.; Wilen, S.H. Enantiomers, Racemates and Resolutions; Krieger Publishing Company: Malabar, FL, USA, 1991.

34. Wang, Y.; Chen, A.M. Enantioenrichment by crystallization. Org. Process Res. Dev. 2008, 12, 282-290. [CrossRef]

35. Buchwald, S.L.; Fisher, R.A.; Foxman, B.M. The synthesis and structure of stibaindoles. Angew. Chem. Int. Ed. 1990, 29, 771-772. [CrossRef] 
36. Chen, C.-F.; Shen, Y. Helicene Chemistry: From Synthesis to Applications; Springer: Berlin/Heidelberg, Germany, 2017.

37. Sheldrick, G.M. SADABS. Program for Empirical Absorption Correction of Area Detector Data; University of Göttingen: Göttingen, Germany, 1996.

38. Sheldrick, G.M. Crystal structure refinement with SHELXL. Acta. Cryst. 2015, C71, 3-8. 